\title{
INSECTICIDE RESISTANCE IN Bemisia tabaci (GENN.) POPULATIONS COLLECTED FROM THE MEDITERRANEAN AND AEGEAN REGIONS OF TURKEY
}

\author{
DAĞLI, F. ${ }^{1 *}-$ YÜKSELBABA, U. ${ }^{1}-$ IKTEN, C. $^{1}-$ TOPAKÇI, N. ${ }^{2}$ - GÖÇMEN, H. ${ }^{1,3}$ \\ ${ }^{1}$ Akdeniz University, Faculty of Agriculture, Department of Plant Protection, 07059 Antalya, \\ Turkey \\ ${ }^{2}$ Akdeniz University, Vocational School of Technical Science, 07059 Antalya, Turkey \\ ${ }^{3}$ Kyrgyz-Turkish Manas University, Faculty of Agriculture, Department of Plant Protection, \\ 720044 Bishkek, Kyrgyzstan \\ ${ }^{*}$ Corresponding author \\ e-mail:fdagli@akdeniz.edu.tr; phone: +90-0-242-310-2426; fax: +90-0-242-310-2479
}

(Received $7^{\text {th }}$ Jul 2020; accepted $17^{\text {th }}$ Sep 2020)

\begin{abstract}
In this study, the resistance status to imidacloprid, lambda-cyhalothrin and endosulfan of twenty Bemisia tabaci (Genn.) populations collected in Hatay, Adana, Mersin, Antalya, Muğla, Aydın and Denizli provinces in the Mediterranean and Aegean regions of Turkey in 2005-2006 were investigated. The lethal concentration (LC) values for each population were determined by the leaf dipping method. The resistance ratios were calculated by dividing the $\mathrm{LC}_{50}$ values of the populations by the $\mathrm{LC}_{50}$ values of a susceptible population. The $\mathrm{LC}_{50}$ values of the $B$. tabaci populations to imidacloprid, lambda-cyhalothrin and endosulfan were found to be in the ranges of 0.1-8.5, 0.7-232.9 and 0.9-21.4 mg ai (=active ingredients)/l, respectively. The imidacloprid, lambda-cyhalothrin and endosulfan resistance ratios were 1-95, 1-439 and 4-102 times, respectively. Generally, the resistance ratio against the lambda-cyhalothrin were higher than against imidacloprid and endosulfan. In addition, in the Kumluca and Demre B. tabaci populations from greenhouses, resistance to the 3 insecticides was found to be between medium and high levels. Based on the results, we determined that a significant proportion of the $B$. tabaci populations in the Mediterranean and Aegean regions are resistant to the active substances in neonicotinoids, pyrethroids and cyclodiene organochlorines.
\end{abstract}

Keywords: cotton whitefly, resistance management, imidacloprid, lambda-cyhalothrin, endosulfan

\section{Introduction}

The development of insecticide resistance in pest populations has become one of the main problems in agricultural production in recent years. Resistance has been recorded in 597 arthropod species for 336 active substances and in 14,644 cases from 1914 to 2015 (IRAC, 2016). However, in agriculture both worldwide and in Turkey, the usage of insecticides in significant quantities is apparent in the statistical data. The annual pesticide usage amount in the world was 2,285,881 tonnes in 1990, and by 2017, it had increased to 4,113,591 tonnes (FAO, 2020). The pesticide usage amount in Turkey in 1990 was 29,918 tonnes, and it had increased to 54,098 tonnes by 2017 (FAO, 2020). When only considering the amount of insecticides used, the USA is in the first place in the world, with 86,726 tons, and Turkey is ranked seventh, with 12,435 tonnes. In Turkey, the five provinces that use the most pesticides and their usage rates are as follows: Antalya (10.1\%), Manisa (9\%), Adana (9\%), Mersin (5.7\%) and Aydin (5.7\%) (Anonymous, 2020). To sum it up, the Mediterranean and Aegean regions are the regions with the most intensive agricultural insecticide use in Turkey. Therefore, greenhouse and field 
populations in these regions are constantly exposed to high selection pressure due to frequent insecticide use.

The cotton whitefly Bemisia tabaci is among the main species for which chemical control is insufficient due to insecticide resistance. $B$. tabaci is one of the most significant agricultural pests and is common worldwide, including Turkey (EPPO, 2020). The adult and larval stages of the pest cause serious damage by sucking plant sap. It decreases the quality and market value of the product by causing sooty mould. It is also a vector of certain important viruses that cause serious economic losses in agricultural production, such as tomato yellow leaf curl virus (TYLCV). It is a polyphagous pest, and its number of hosts is very high. It causes serious economic losses by feeding on many industrial plants, ornamental plants, vegetables, especially tomato, eggplant, pepper, cucumber, etc., and cotton (Göçmen and Özgür, 1990; Hoddle, 1999; Oliveira et al., 2001). In Turkey and other countries whitefly management is still based largely on insecticides. However, insecticide resistance is a major problem in $\mathrm{B}$. tabaci populations worldwide (Wool and Greenberg, 1990; Dittrich et al., 1990; Cahill et al., 1996; Elebert and Nauen, 2000; Palumbo et al., 2001; Kranthi et al., 2002; Ahmad et al., 2002; Nauen et al., 2002; El Kady and Devine, 2003; Javed et al., 2003; Horowitz et al., 2004, 2005; Roditakis et al., 2005; Nauen and Denholm, 2005; Erdoğan et al., 2008; Basij et al., 2010; Gorman et al., 2010; Ma et al., 2010; Schuster et al., 2010; Wang et al., 2010; Ünal Bahşi et al.,2012; Şahin and İkten, 2017; Ahmad and Akhtar, 2018; Satar et al., 2018; Bielza et al., 2019). Resistance to 56 different active substances has been reported in $B$. tabaci populations (APRD, 2020). Among these active ingredients, the best known are imidacloprid, acetamiprid, thiamethoxam (neonicotinoids); cypermethrin, deltamethrin, (pyrethroids); chlorpyrifos, malathion (organophosphates); methomyl, carbosulfan (carbamates); pyriproxyfen (juvenile hormone mimics); spiromesifen, spirotetramat (tetronic and tetramic acid derivatives); and endosulfan (cyclodiene organochlorines) (APRD, 2020).

It has been reported that insecticides should be used within the scope of "resistance management programmes", and the frequency of insecticide application should be reduced to combat the insecticide resistance problem (Soderlund and Bloomquist, 1990). Resistance screening studies reveal populations' resistance to insecticides, and routine monitoring is essential for insecticide resistance management (Croft, 1990).

In this study, twenty B. tabaci populations were collected in Hatay, Adana, Mersin, Antalya, Muğla, Aydın and Denizli provinces in the Mediterranean and Aegean regions of Turkey. The resistance status of these populations to imidacloprid (neonicotinoids), lambda-cyhalothrin (pyrethroids) and endosulfan (cyclodiene organochlorines) was investigated. The findings obtained in this study on $\mathrm{B}$. tabaci provide important information for comparison to past records or for recording the initial phase of insecticide resistance in populations from Turkey. The data presented here can be a valuable resource for researchers on this subject.

\section{Materials and Methods}

\section{Populations}

Twenty population of Bemisia tabaci were collected from south-west region of Turkey. These sampling locations were indicated on the map in Figure 1.

Furthermore, the location, host and collection dates of $B$. tabaci populations tested within the scope of the study are given in Table 1. 


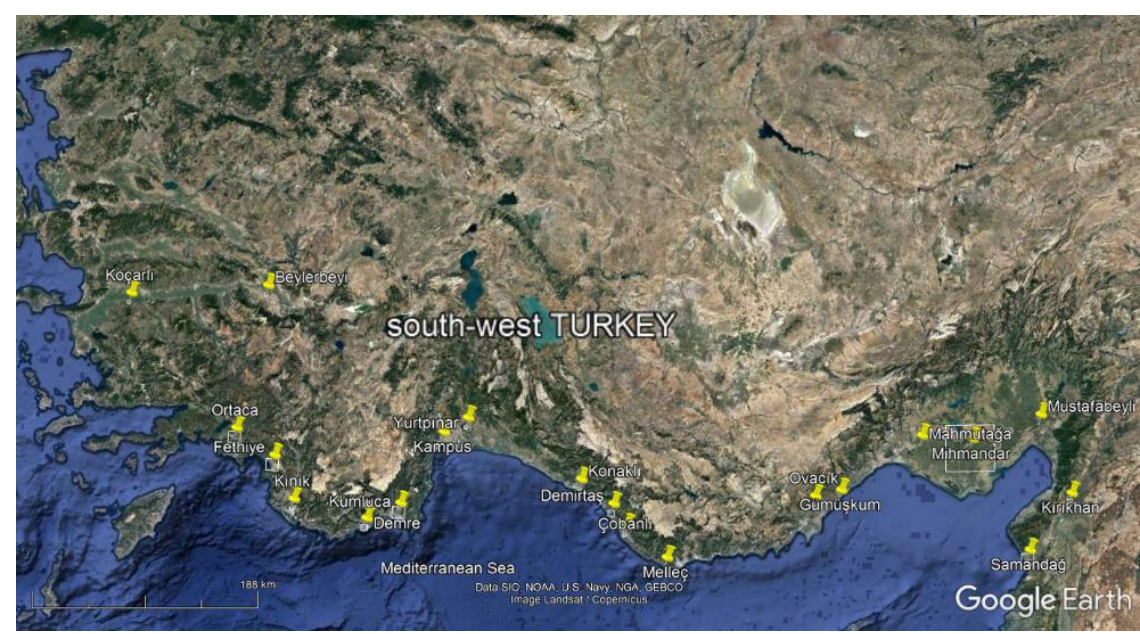

Figure 1. Sampling locations of the Bemisia tabaci populations were indicated on the map

Table 1. Sampling locations, host plants and biotypes of the Bemisia tabaci (Dağll et al., 2020)

\begin{tabular}{|c|c|c|c|}
\hline Location & Host & Sampling Date & Biotype \\
\hline $\begin{array}{c}\text { HATAY } \\
\text { Kırıkhan-(Hassa) } \\
\text { Samandağ } \\
\end{array}$ & $\begin{array}{l}\text { Cucumber } \\
\text { Eggplant }\end{array}$ & $\begin{array}{l}03.09 .2005 \\
03.09 .2005 \\
\end{array}$ & $\begin{array}{l}\text { Qe } \\
\text { B }\end{array}$ \\
\hline $\begin{array}{c}\text { ADANA } \\
\text { Mihmandar } \\
\text { Mustafabeyli }\end{array}$ & $\begin{array}{c}\text { Cotton and soybean } \\
\text { Cucumber }\end{array}$ & $\begin{array}{l}02.09 .2005 \\
02.09 .2005\end{array}$ & $\begin{array}{l}\text { Qe } \\
\text { Qe }\end{array}$ \\
\hline $\begin{array}{c}\text { MERSİN (İÇEL) } \\
\text { Mahmutağa (Tarsus) } \\
\text { Gümüşkum } \\
\text { Ovacık (Silifke) } \\
\text { Melleç (Anamur) }\end{array}$ & $\begin{array}{l}\text { Eggplant } \\
\text { Eggplant } \\
\text { Eggplant } \\
\text { Nightshade }\end{array}$ & $\begin{array}{l}04.09 .2005 \\
04.09 .2005 \\
04.09 .2005 \\
01.09 .2005\end{array}$ & $\begin{array}{l}\text { B } \\
\text { B } \\
\text { B } \\
\text { B }\end{array}$ \\
\hline $\begin{array}{c}\text { ANTALYA } \\
\text { Yurtpınar (Aksu) } \\
\text { Kampus (Uncalı) } \\
\text { Konaklı (Alanya) } \\
\text { Çobanlı (Gazipaşa) } \\
\text { Demirtaş (Alanya) } \\
\text { Kumluca } \\
\text { Demre }\end{array}$ & $\begin{array}{l}\text { Eggplant } \\
\text { Cotton } \\
\text { Eggplant } \\
\text { Cucumber } \\
\text { Eggplant } \\
\text { Pepper } \\
\text { Pepper }\end{array}$ & $\begin{array}{l}30.09 .2005 \\
28.11 .2005 \\
30.09 .2005 \\
30.09 .2005 \\
30.09 .2005 \\
05.07 .2006 \\
05.07 .2006\end{array}$ & $\begin{array}{c}\text { B } \\
\text { B } \\
\text { B } \\
\text { B } \\
\text { B } \\
\text { Qe } \\
\text { Qe }\end{array}$ \\
\hline $\begin{array}{c}\text { MUĞLA } \\
\text { Kınık } \\
\text { Fethiye } \\
\text { Ortaca }\end{array}$ & $\begin{array}{l}\text { Cotton } \\
\text { Eggplant } \\
\text { Cucumber }\end{array}$ & $\begin{array}{l}17.08 .2006 \\
18.08 .2006 \\
18.08 .2006 \\
\end{array}$ & $\begin{array}{l}\mathrm{B} \\
\mathrm{B} \\
\mathrm{B}\end{array}$ \\
\hline $\begin{array}{l}\text { AYDIN } \\
\text { Koçarlı }\end{array}$ & Cotton & 18.08 .2006 & Qw \\
\hline $\begin{array}{l}\text { DENIZZLI } \\
\text { Beylerbeyi }\end{array}$ & Cotton & 19.08 .2006 & Qw \\
\hline
\end{tabular}

\section{Insecticides}

Detailed information about the active substances used in the study is given in Table 2. The neonicotinoid imidacloprid and the pyrethroid lambda-cyhalothrin are still registered in Turkey. However, the use of the cyclodiene organochlorine endosulfan was banned in Turkey. 
Table 2. Active ingredients and commercial names for insecticides and their mode of action

\begin{tabular}{c|c|c|c}
\hline Active substance & $\begin{array}{c}\text { Commercial name and } \\
\text { formulations }\end{array}$ & $\begin{array}{c}\text { Chemical classification and mode of } \\
\text { action (IRAC, 2020) }\end{array}$ & $\begin{array}{c}\text { Recommended label dose (mg } \\
\text { ai)/l }\end{array}$ \\
\hline imidacloprid & Confidor SC 350, Bayer & $\begin{array}{c}\text { Neonicotinoids, 4A, Nicotinic } \\
\text { acetylcholine receptor (nAChR) } \\
\text { competitive modulators }\end{array}$ & $350 \mathrm{mg}$ ai/l \\
\hline lambda-cyhalothrin & $\begin{array}{c}\text { KarateZeon CS, } \\
\text { Syngenta }\end{array}$ & $\begin{array}{c}\text { Pyrethroids, 3A, Sodium channel } \\
\text { modulators }\end{array}$ & $25 \mathrm{mg}$ ai /1 \\
\hline endosulfan & Hektionex 36 EC, Hektaş & $\begin{array}{c}\text { Cyclodien organochlorine, 2A, } \\
\text { GABA-gated chloride channel } \\
\text { blockers }\end{array}$ & $540 \mathrm{mg}$ ai /l \\
\hline
\end{tabular}

\section{Insect Rearing}

Bemisia tabaci adults were collected with a mouth aspirator from the locations specified in Table 1. The adults were released on cotton and eggplant seedlings in 20 litre plastic containers covered with tulle to lay. Populations were kept in a climate-controlled room with a temperature of $26 \pm 2{ }^{\circ} \mathrm{C}$ and 16:8 (light:dark) hours per day.

\section{Insecticide Bioassay}

The leaf dipping method was used to determine the $\mathrm{LC}_{50}$ and $\mathrm{LC}_{90}$ values of the populations (Roditakis et al., 2005). Briefly, the method is as follows: To obtain a distribution of death between $0 \%$ and $100 \%$ in B. tabaci populations, 4-6 different doses of these insecticides were prepared in distilled water containing $0.2 \mathrm{~g} / 1$ Triton X-100. Discs with a diameter of $48 \mathrm{~mm}$ were taken from insecticide-free cotton leaves. These leaf discs were immersed in distilled water containing insecticide concentrations or the control (only $0.2 \mathrm{~g} / 1$ Triton X-100) for 5 seconds and allowed to dry for approximately 2 hours. These leaf discs were placed in Petri dishes containing $1.5 \%$ agar poured onto the base of the dish. Adult individuals were shaken directly into these Petri dishes, and each Petri dish was covered with a cotton cloth. Each dose was conducted with 3 replicates. Bioassays were performed on 3 days for imidacloprid and on 2 days for lambda-cyhalothrin and endosulfan.

\section{Data Analysis}

In the study, a Bemisia tabaci population was collected from a cotton field in Koçarlı where no pesticides were used for a long time to be used as a susceptible population. The probit analysis program POLO-PC was used to calculate the lethal dose values $\left(\mathrm{LC}_{50}\right.$, $\mathrm{LC}_{90}$ ) and the related parameters of the populations, and the $\mathrm{LC}_{50}$ values of the populations were divided by $\mathrm{LC}_{50}$ values of a susceptible (Koçarl1) population to calculate the resistance ratio. Any two LC50 values were considered significantly different if their respective $95 \%$ confidence limits (CL) did not overlap.

\section{Results}

The lethal dose values (LC), slopes, resistance ratios and related parameters obtained from B. tabaci populations in the screening for imidacloprid, lambda-cyhalothrin and endosulfan resistance are given in Tables 3, 4 and 5, respectively. The results showed that there were significant differences between the $\mathrm{LC}$ values of the populations. Considering the $\mathrm{LC}_{50}$ and $\mathrm{LC}_{90}$ values of all populations, Koçarlı (Aydın) was determined to be the 
most susceptible population. Insecticides stopped being used many years ago in cotton fields in which the Koçarl population was collected. In this population, the $\mathrm{LC}_{50}$ values ( 0.2 and $0.09 \mathrm{mg}$ ai/l) obtained for endosulfan and imidacloprid were lower than the $\mathrm{LC}_{50}$ values of the reference susceptible population (SUD-S) $(1.65$ and $0.36 \mathrm{mg}$ ai/l) determined by Roditakis et al. (2005) for the same insecticides with the same method. Based on these data, Koçarlı was considered a susceptible population, and the $\mathrm{LC}_{50}$ values of the other field and greenhouse populations were divided by the $\mathrm{LC}_{50}$ values of the Koçarlı population to obtain their resistance ratios.

Table 3. The resistance ratios to imidacloprid in Bemisia tabaci populations collected from Mediterranean and Aegean regions of Turkey

\begin{tabular}{|c|c|c|c|c|c|}
\hline Population & $\mathbf{n}$ & slope \pm se & $\begin{array}{c}\mathbf{L C} \mathbf{C}_{\mathbf{5 0}}(\mathbf{m g} \text { ai/l }) \\
95 \% \text { confidence limits }\end{array}$ & 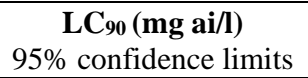 & $\mathbf{R R}$ \\
\hline $\begin{array}{c}\text { Koçarlı } \\
\text { (Susceptible) }\end{array}$ & 301 & $1.47 \pm 0.22$ & $\begin{array}{c}\mathbf{0 . 0 9} \\
0.02-0.18 \\
\end{array}$ & $\begin{array}{c}\mathbf{0 . 6 5} \\
0.34-2.15 \\
\end{array}$ & - \\
\hline Mustafabeyli & 188 & $0.92 \pm 0.14$ & $\begin{array}{c}\mathbf{0 . 0 8} \\
0.01-0.30 \\
\end{array}$ & $\begin{array}{c}\mathbf{2 . 0 9} \\
0.55-34.02 \\
\end{array}$ & 0.9 \\
\hline Mahmutağa & 332 & $1.00 \pm 0.14$ & $\begin{array}{c}\mathbf{0 . 3 9} \\
0.07-0.99\end{array}$ & $\begin{array}{c}\mathbf{7 . 2 8} \\
2.80-50.56\end{array}$ & 4.3 \\
\hline Gümüşkum & 186 & $1.76 \pm 0.39$ & $\begin{array}{c}\mathbf{1 . 3 9} \\
0.58-2.55 \\
\end{array}$ & $\begin{array}{c}\mathbf{7 . 4 6} \\
3.93-24.09 \\
\end{array}$ & 15.4 \\
\hline Ovacık & 351 & $0.71 \pm 0.09$ & $\begin{array}{c}\mathbf{0 . 0 6} \\
0.00-0.21 \\
\end{array}$ & $\begin{array}{c}\mathbf{4 . 1 2} \\
1.15-58.43 \\
\end{array}$ & 0.7 \\
\hline Melleç & 182 & $0.87 \pm 0.16$ & $\begin{array}{c}\mathbf{0 . 1 0} \\
0.00-0.41 \\
\end{array}$ & $\begin{array}{c}\mathbf{3 . 0 7} \\
0.72-918.12 \\
\end{array}$ & 1.1 \\
\hline Yurtpinar & 265 & $1.17 \pm 0.14$ & $\begin{array}{c}\mathbf{0 . 2 4} \\
0.08-0.59\end{array}$ & $\begin{array}{c}\mathbf{2 . 9 9} \\
1.10-20.97\end{array}$ & 2.7 \\
\hline Kampus & 275 & $1.04 \pm 0.11$ & $\begin{array}{c}\mathbf{0 . 5 7} \\
0.37-0.88\end{array}$ & $\begin{array}{c}\mathbf{9 . 9 2} \\
5.38-23.30\end{array}$ & 6.3 \\
\hline Konaklı & 227 & $0.94 \pm 0.11$ & $\begin{array}{c}\mathbf{1 . 1 1} \\
0.32-3.52 \\
\end{array}$ & $\begin{array}{c}\mathbf{2 5 . 7 4} \\
6.81-675.00 \\
\end{array}$ & 12.3 \\
\hline Çobanlı & 154 & $1.45 \pm 0.32$ & $\begin{array}{c}\mathbf{0 . 6 9} \\
0.23-1.28\end{array}$ & $\begin{array}{c}\mathbf{5 . 3 3} \\
2.95-14.53\end{array}$ & 7.7 \\
\hline Demirtaş & 157 & $3.22 \pm 0.81$ & $\begin{array}{c}\mathbf{8 . 5 1} \\
0.83-17.64 \\
\end{array}$ & $\begin{array}{c}\mathbf{2 1 . 2 9} \\
8.42-67.13 \\
\end{array}$ & 94.6 \\
\hline Kumluca & 223 & $1.41 \pm 0.19$ & $\begin{array}{c}\mathbf{2 . 2 2} \\
1.26-3.71\end{array}$ & $\begin{array}{c}\mathbf{1 7 . 9 5} \\
9.93-42.05\end{array}$ & 24.7 \\
\hline Demre & 209 & $1.19 \pm 0.18$ & $\begin{array}{c}\mathbf{1 . 6 1} \\
0.79-2.96\end{array}$ & $\begin{array}{c}\mathbf{1 9 . 1 8} \\
9.51-55.23\end{array}$ & 17.9 \\
\hline Kınık & 326 & $1.46 \pm 0.18$ & $\begin{array}{c}\mathbf{0 . 8 7} \\
0.49-1.45 \\
\end{array}$ & $\begin{array}{c}\mathbf{6 . 5 9} \\
3.56-18.23 \\
\end{array}$ & 9.7 \\
\hline Fethiye & 430 & $1.41 \pm 0.17$ & $\begin{array}{c}\mathbf{0 . 8 8} \\
0.38-1.91 \\
\end{array}$ & $\begin{array}{c}\mathbf{7 . 1 8} \\
3.08-33.46 \\
\end{array}$ & 9.8 \\
\hline Ortaca & 410 & $1.23 \pm 0.13$ & $\begin{array}{c}\mathbf{0 . 7 2} \\
0.14-2.30 \\
\end{array}$ & $\begin{array}{c}\mathbf{7 . 9 8} \\
2.46-129.53 \\
\end{array}$ & 8.0 \\
\hline Beylerbeyi & 178 & $3.04 \pm 0.72$ & $\begin{array}{c}\mathbf{0 . 1 0} \\
0.07-0.15\end{array}$ & $\begin{array}{c}\mathbf{0 . 2 6} \\
0.17-0.72\end{array}$ & 1.1 \\
\hline
\end{tabular}

$\mathbf{n}$ : Total number of insects used in the experiment

Resistance Ratio (RR): $\mathrm{LC}_{50}$ values of the populations / the $\mathrm{LC}_{50}$ values of a susceptible population

\section{Resistance to Imidacloprid}

Imidacloprid, which has been registered in Turkey since 1994, is a systemic insecticide and is widely used. Within the scope of this research, 17 populations were assayed to imidacloprid (Table 3). The $\mathrm{LC}_{50}$ value range to imidacloprid in populations was found 
to be $0.1-8.5 \mathrm{mg}$ ai/l. The resistance ratios were between 1-95 times the resistance of the susceptible population. In the Demirtaş, Kumluca, Demre, Gümüşkum, Konaklı, Kınık and Fethiye populations, resistance between moderate and high levels was detected. In other populations, resistance was at a low level, below 10 times the resistance of the susceptible population.

\section{Resistance to Lambda-cyhalothrin}

Lambda-cyhalothrin, which is in the pyrethroid class, has been registered since 1988 in Turkey. It can be used alone as a single active ingredient or in mixture with buprofezin.

Fifteen populations were tested to lambda-cyhalothrin (Table 4). The $\mathrm{LC}_{50}$ values of the populations for lambda-cyhalothrin were found to be between 0.7-232.9 mg a.i./litre. The resistance ratios were between 1-439 times. In most populations taken from greenhouses, resistance to this insecticide was between medium and high levels. On the other hand, resistance was under 10 times the resistance of the susceptible population in the Kırıkhan, Samandağı, Mihmandar, Mahmutağa and Beylerbeyi populations (Table 4).

Table 4. The resistance ratios to lamda-cyhalothrin in Bemisia tabaci populations collected from Mediterranean and Aegean regions of Turkey

\begin{tabular}{|c|c|c|c|c|c|}
\hline Population & $\mathbf{n}$ & slope \pm se & $\begin{array}{c}\mathbf{L C}_{\mathbf{5 0}}(\mathbf{m g} \text { ai/l/) } \\
95 \% \text { confidence limits }\end{array}$ & $\begin{array}{c}\mathbf{L} \mathbf{C}_{\mathbf{9 0}}(\mathbf{m g} \text { ai/l) }) \\
95 \% \text { confidence limits }\end{array}$ & $\mathbf{R R}$ \\
\hline $\begin{array}{c}\text { Koçarlı } \\
\text { (Susceptible) }\end{array}$ & 171 & $1.56 \pm 0.42$ & $\begin{array}{c}\mathbf{0 . 5 3} \\
0.19-1.04 \\
\end{array}$ & $\begin{array}{c}\mathbf{3 . 5 1} \\
1.65-21.82 \\
\end{array}$ & - \\
\hline Kırıkhan & 174 & $1.72 \pm 0.39$ & $\begin{array}{c}\mathbf{3 . 4 8} \\
0.63-7.33\end{array}$ & $\begin{array}{c}\mathbf{1 9 . 1 9} \\
9.02-134.84\end{array}$ & 6.6 \\
\hline Samandağ & 78 & $1.19 \pm 0.35$ & $\begin{array}{c}\mathbf{1 . 0 4} \\
0.16-2.78\end{array}$ & $\begin{array}{c}\mathbf{1 2 . 3 9} \\
4.47-145.95\end{array}$ & 2.0 \\
\hline Mihmandar & 302 & $0.90 \pm 0.15$ & $\begin{array}{c}\mathbf{1 . 0 5} \\
0.14-2.92 \\
\end{array}$ & $\begin{array}{c}\mathbf{2 7 . 7 2} \\
10.54-147.32 \\
\end{array}$ & 2.0 \\
\hline Mahmutağa & 308 & $0.59 \pm 0.07$ & $\begin{array}{c}1.19 \\
0.07-8.62 \\
\end{array}$ & $\begin{array}{c}\mathbf{1 9 5 . 8 8} \\
24.30-11606.28 \\
\end{array}$ & 2.2 \\
\hline Melleç & 423 & $1.31 \pm 0.22$ & $\begin{array}{c}\mathbf{1 2 . 3 9} \\
5.20-21.38\end{array}$ & $\begin{array}{c}\mathbf{1 1 8 . 4 4} \\
70.81-254.34\end{array}$ & 23.4 \\
\hline Yurtpınar & 284 & $0.60 \pm 0.06$ & $\begin{array}{c}\mathbf{4 0 . 9 1} \\
5.23-400.36\end{array}$ & $\begin{array}{c}\mathbf{5 5 8 5 . 6 2} \\
526.10-2019588.89\end{array}$ & 77.2 \\
\hline Kampus & 351 & $0.75 \pm 0.09$ & $\begin{array}{c}\mathbf{3 3 . 1 9} \\
5.13-110.57 \\
\end{array}$ & $\begin{array}{c}\mathbf{1 7 3 0 . 5 6} \\
497.56-14037.95 \\
\end{array}$ & 62.6 \\
\hline Çobanlı & 370 & $2.02 \pm 0.59$ & $\begin{array}{c}\mathbf{2 3 2 . 8 6} \\
21.97-447.62 \\
\end{array}$ & $\begin{array}{c}\mathbf{1 0 0 5 . 0 7} \\
548.23-3301.06\end{array}$ & 439.4 \\
\hline Kumluca & 231 & $0.95 \pm 0.13$ & $\begin{array}{c}\mathbf{4 2 . 6 1} \\
11.26-128.30 \\
\end{array}$ & $\begin{array}{c}\mathbf{9 5 5 . 1 8} \\
279.24-11230.23 \\
\end{array}$ & 80.4 \\
\hline Demre & 289 & $0.58 \pm 0.08$ & $\begin{array}{c}\mathbf{1 4 0 . 7 7} \\
22.55-1200.94\end{array}$ & $\begin{array}{c}\mathbf{2 3 7 1 5 . 7 4} \\
2196.34-41168269.34\end{array}$ & 256.6 \\
\hline Kınık & 493 & $1.28 \pm 0.19$ & $\begin{array}{c}\mathbf{4 3 . 9 2} \\
11.94-91.39 \\
\end{array}$ & $\begin{array}{c}\mathbf{4 4 2 . 4 1} \\
221.55-1307.91 \\
\end{array}$ & 82.9 \\
\hline Fethiye & 315 & $1.11 \pm 0.15$ & $\begin{array}{c}\mathbf{5 . 2 2} \\
2.52-11.27\end{array}$ & $\begin{array}{c}\mathbf{7 5 . 2 8} \\
30.69-284.94\end{array}$ & 9.8 \\
\hline Ortaca & 595 & $1.36 \pm 0.13$ & $\begin{array}{c}\mathbf{1 4 . 7 4} \\
8.00-28.86\end{array}$ & $\begin{array}{c}\mathbf{1 2 8 . 4 2} \\
57.35-538.80\end{array}$ & 27.8 \\
\hline Beylerbeyi & 234 & $0.77 \pm 0.13$ & $\begin{array}{c}\mathbf{0 . 7 3} \\
0.02-4.21 \\
\end{array}$ & $\begin{array}{c}\mathbf{3 2 . 9 8} \\
5.47-9980.88 \\
\end{array}$ & 1.4 \\
\hline
\end{tabular}

n: Total number of insects used in the experiment

Resistance Ratio (RR): $\mathrm{LC}_{50}$ values of the populations / the $\mathrm{LC}_{50}$ values of a susceptible population 


\section{Resistance to Endosulfan}

Endosulfan, which is in the cyclodiene class, has been used as a registered insecticide since 1954. It is one of the oldest insecticides used in Turkey and worldwide. Its use was banned in Turkey in 2010. In this study, 19 populations were assayed to endosulfan (Table 5). The $\mathrm{LC}_{50}$ value range of the populations for endosulfan was found to be 0.9-21.4 mg ai/l. The resistance ratios were between 4-102 times. Resistance was high in the Kumluca, Demre, Ortaca, Kınık and Fethiye populations. Resistance was at moderate levels in the Mahmutağa, Gümüşkum, Yurtpınar, Kampüs and Konaklı populations.

Resistance was low in the Beylerbeyi, Demirtaş, Kırıkhan-Hassa, Melleç, Mihmandar, Ovacık and Samandağ populations (Table 5).

Table 5. The resistance ratios to endosulfan in Bemisia tabaci populations collected from Mediterranean and Aegean regions of Turkey

\begin{tabular}{|c|c|c|c|c|c|}
\hline Population & $\mathbf{n}$ & slope \pm se & $\begin{array}{c}\mathbf{L C}_{\mathbf{5 0}}(\mathbf{m g} \mathbf{a i} / \mathbf{l}) \\
95 \% \text { confidence limits }\end{array}$ & $\begin{array}{c}\mathbf{L} \mathbf{C}_{\mathbf{9 0}}(\mathbf{m g} \text { ai/l/ }) \\
95 \% \text { confidence limits }\end{array}$ & $\mathbf{R R}$ \\
\hline $\begin{array}{c}\text { Koçarlı } \\
\text { (Susceptible) }\end{array}$ & 342 & $1.02 \pm 0.13$ & $\begin{array}{c}\mathbf{0 . 2 1} \\
0.07-0.45 \\
\end{array}$ & $\begin{array}{c}\mathbf{3 . 8 9} \\
1.86-11.16 \\
\end{array}$ & - \\
\hline Kırıkhan & 309 & $4.33 \pm 0.51$ & $\begin{array}{c}\mathbf{1 . 8 3} \\
1.53-2.19 \\
\end{array}$ & $\begin{array}{c}\mathbf{3 . 6 2} \\
2.95-4.79 \\
\end{array}$ & 8.7 \\
\hline Samandağ & 269 & $2.21 \pm 0.41$ & $\begin{array}{c}\mathbf{1 . 3 7} \\
0.49-2.11 \\
\end{array}$ & $\begin{array}{c}\mathbf{5 . 1 9} \\
3.66-9.21 \\
\end{array}$ & 6.5 \\
\hline Mihmandar & 313 & $1.85 \pm 0.22$ & $\begin{array}{c}\mathbf{1 . 9 8} \\
1.26-2.95\end{array}$ & $\begin{array}{c}\mathbf{9 . 7 2} \\
5.87-23.73 \\
\end{array}$ & 9.4 \\
\hline Mustafabeyli & 178 & $4.88 \pm 0.96$ & $\begin{array}{c}\mathbf{2 . 2 5} \\
1.54-3.08\end{array}$ & $\begin{array}{c}\mathbf{4 . 1 3} \\
3.02-6.51 \\
\end{array}$ & 10.7 \\
\hline Mahmutağa & 284 & $2.07 \pm 0.30$ & $\begin{array}{c}\mathbf{3 . 8 0} \\
2.35-7.95 \\
\end{array}$ & $\begin{array}{c}\mathbf{1 5 . 8 0} \\
7.67-260.26 \\
\end{array}$ & 18.1 \\
\hline Gümüşkum & 306 & $4.95 \pm 1.41$ & $\begin{array}{c}\mathbf{3 . 5 1} \\
2.27-4.43 \\
\end{array}$ & $\begin{array}{c}\mathbf{6 . 3 8} \\
4.96-13.73 \\
\end{array}$ & 16.7 \\
\hline Ovacık & 102 & $2.95 \pm 0.78$ & $\begin{array}{c}\mathbf{1 . 5 0} \\
0.34-2.44 \\
\end{array}$ & $\begin{array}{c}\mathbf{4 . 0 8} \\
2.51-13.52 \\
\end{array}$ & 7.1 \\
\hline Melleç & 240 & $2.72 \pm 0.38$ & $\begin{array}{c}\mathbf{0 . 8 5} \\
0.57-1.21 \\
\end{array}$ & $\begin{array}{c}\mathbf{2 . 5 1} \\
1.66-5.63 \\
\end{array}$ & 4.0 \\
\hline Yurtpınar & 254 & $1.49 \pm 0.22$ & $\begin{array}{c}\mathbf{3 . 2 7} \\
1.00-7.54 \\
\end{array}$ & $\begin{array}{c}\mathbf{2 3 . 6 5} \\
9.65-322.10 \\
\end{array}$ & 15.6 \\
\hline Kampus & 286 & $2.28 \pm 0.26$ & \begin{tabular}{c|}
$\mathbf{3 . 6 6}$ \\
$2.40-5.83$ \\
\end{tabular} & $\begin{array}{c}\mathbf{1 3 . 3 6} \\
7.87-35.88 \\
\end{array}$ & 17.4 \\
\hline Konaklı & 680 & $8.96 \pm 1.19$ & $\begin{array}{c}\mathbf{2 . 6 8} \\
2.28-3.10 \\
\end{array}$ & $\begin{array}{c}\mathbf{3 . 7 3} \\
3.20-6.13 \\
\end{array}$ & 12.8 \\
\hline Demirtaş & 590 & $1.77 \pm 0.20$ & $\begin{array}{c}\mathbf{1 . 5 1} \\
0.80-2.31 \\
\end{array}$ & $\begin{array}{c}\mathbf{7 . 9 9} \\
4.67-27.20 \\
\end{array}$ & 7.2 \\
\hline Kumluca & 123 & $2.67 \pm 0.47$ & $\begin{array}{c}\mathbf{2 1 . 4 2} \\
14.18-34.27\end{array}$ & $\begin{array}{c}\mathbf{6 4 . 8 0} \\
39.43-153.35 \\
\end{array}$ & 102.0 \\
\hline Demre & 345 & $1.05 \pm 0.12$ & $\begin{array}{c}\mathbf{1 3 . 7 0} \\
3.77-34.69 \\
\end{array}$ & $\begin{array}{c}\mathbf{2 2 9 . 5 3} \\
78.74-2565.15 \\
\end{array}$ & 65.2 \\
\hline Kınık & 284 & $1.05 \pm 0.12$ & $\begin{array}{c}\mathbf{7 . 2 3} \\
4.41-11.10 \\
\end{array}$ & $\begin{array}{c}\mathbf{2 3 . 0 8} \\
14.32-62.74 \\
\end{array}$ & 34.4 \\
\hline Fethiye & 526 & $2.75 \pm 0.41$ & $\begin{array}{c}\mathbf{7 . 8 5} \\
5.78-10.91 \\
\end{array}$ & $\begin{array}{c}\mathbf{2 2 . 9 4} \\
15.33-49.88 \\
\end{array}$ & 37.4 \\
\hline Ortaca & 586 & $2.94 \pm 0.36$ & $\begin{array}{c}\mathbf{1 6 . 7 7} \\
10.41-23.72 \\
\end{array}$ & $\begin{array}{c}\mathbf{4 5 . 7 4} \\
32.46-71.89 \\
\end{array}$ & 79.9 \\
\hline Beylerbeyi & 230 & $1.30 \pm 0.2$ & $\begin{array}{c}\mathbf{1 . 0 8} \\
0.44-2.39 \\
\end{array}$ & $\begin{array}{c}\mathbf{1 0 . 4 3} \\
4.28-56.20 \\
\end{array}$ & 5.1 \\
\hline
\end{tabular}

n: Total number of insects used in the experiment

Resistance Ratio (RR): $\mathrm{LC}_{50}$ values of the populations / the $\mathrm{LC}_{50}$ values of a susceptible population 


\section{Discussion}

In general, resistance against lambda-cyhalothrin in the pyrethroid class in populations was higher than resistance to imidacloprid and endosulfan. In B. tabaci populations taken from greenhouses, such as the Kumluca and Demre populations, resistance to all 3 insecticides was higher than that in other field populations (Tables 3-5). The main reason for this situation is that the more frequent insecticide applications in greenhouses result in higher selection pressure on populations. Most greenhouses in Turkey are located in Antalya province. In terms of the rates of insecticide use, Antalya takes first place in Turkey, with a rate of $10.1 \%$. These data show that greenhouse populations are exposed to more insecticides than other field populations in other regions. Whitefly populations continue to exist in greenhouses almost throughout the year. In addition, due to the virus vectors, insecticide application is carried out at very short intervals. As a result, the more frequent insecticide applications in greenhouses cause an increase in selection pressure, which provides an important advantage to resistance development. In addition, the fact that greenhouses are relatively closed areas can prevent susceptible individuals from entering from the outside, preventing a decrease in the resistance of the current population from occurring. On the other hand, low levels of resistance were generally found in the Eastern Mediterranean (Kırıkhan, Samandağ, Mihmandar, Mustafabeyli, Ovacık) and Western Aegean (Koçarl1, Beylerbeyi) populations. These populations are field populations, and they are exposed to lower insecticide applications than the greenhouse populations. Another reason why these populations are less resistant is that they are almost always in interaction with susceptible individuals in the natural vegetation around them, so some level of resistance dilution occurs.

In this study, it was determined that a significant number of the tested field and greenhouse populations were highly resistant compared to the susceptible population. The resistance levels in populations increased to 95, 439 and 102 times for imidacloprid, lambda-cyhalothrin and endosulfan, respectively. However, the extent to which the resistance ratios determined how impact insecticide practices should also be evaluated. To analyse to what extent resistance will negatively affect the success of insecticide applications in practice, the label-recommended doses of insecticides were compared with the $\mathrm{LC}_{90}$ dose values (cause $90 \%$ mortality in populations). The $\mathrm{LC}_{90}$ dose values of imidacloprid and endosulfan for all populations (for imidacloprid: 0.3-25.7; for endosulfan: $3.6-229.5 \mathrm{mg}$ ai/l) were below the label doses of these insecticides (imidacloprid: $350 \mathrm{mg}$ ai/l; endosulfan: $540 \mathrm{mg}$ ai/l) (Tables 3 and 5). Accordingly, it can be expected that these two insecticides can still be successful in controlling $B$. tabaci. However, the detected high resistance indicates that there are significantly resistant individuals among the populations. The frequent use of these insecticides can lead to a rapid increase in the frequency of resistant individuals due to selection, and the LC 90 values for the populations can easily exceed the label doses of these insecticides. In this case, the application of these insecticides will lead to control failure. For this reason, the frequency of imidacloprid and endosulfan applications in greenhouse locations with highly resistant populations must be limited. On the other hand, except for that in 2 populations, the $\mathrm{LC}_{90}$ dose value (12.4-23715.7 $\mathrm{mg}$ ai/l) obtained for lambda-cyhalothrin was well above the label dose of this insecticide (25 mg ai/l) (Table 4). Accordingly, when lambda-cyhalothrin is used alone, it will be ineffective against $B$. tabaci in almost all sampling locations. This active ingredient is also used in combination with the IGR class buprofezin. Using lambda-cyhalothrin this mixture can increase the chances of its success in practice. Endosulfan, one of the world's oldest insecticides, was banned years 
ago. Even if endosulfan was banned years ago, endosulfan-resistant populations may not disappear in a short time. These resistant populations can maintain their populations longer in places such as greenhouses where susceptible insect migration is limited. Therefore, these resistant populations should be considered in the implementation of any resistance management program.

Some research has been done on the insecticide resistance of $B$. tabaci populations in Turkey. Four B. tabaci populations were collected from Adana, Antalya, İzmir and Tarsus in 2000-2001, and the resistance levels of these populations to bifenthrin, fenpropathrin (pyrethroids), formothion, triazophos (organophosphates) and buprofezin (insect growth regulator) active substances were determined (Erdoğan et al., 2008). All of the populations showed significant resistance to active substances with pyrethroids (57-360 times) and organophosphates (20-310 times). However, only the İzmir population was found to be resistant to buprofezin (Erdoğan et al., 2008). The resistance status of B. tabaci populations collected from Antalya and its districts between 2007 and 2009 was investigated in terms of resistance to these three insecticides in the populations (Ünal Bahşi et al.,2012) and were found to be 6-299, 2-16 and 1-22 times, respectively. In addition, the recommended label doses of these 3 insecticides remained below the the population $\mathrm{LC}_{90}$ values. In short, these active substances will be ineffective for $B$. tabaci population control in the sampling locations (Ünal Bahşi et al.,2012). In another study, B. tabaci populations from five different locations in Antalya were collected in 2011, and the resistance status of these populations to acetamiprid and thiamethoxam was determined (Şahin and İkten, 2017). The resistance ranges to these insecticides in populations were found to be 4-30 times and 9-32 times the resistance of a susceptible population, respectively. In this study, as in the previous study, it was reported that the label doses of these 2 active substances were below the population $\mathrm{LC}_{90}$ values. Briefly, these active substances will also fail in $B$. tabaci control at the locations that were sampled (Şahin and İkten, 2017). In another study conducted in Turkey, in Mersin, Adana, Antalya and Hatay in the Mediterranean region, the resistance levels of the provincial $\mathrm{B}$. tabaci populations to the neonicotinoid class active substances acetamiprid, imidacloprid, thiacloprid and thiamethoxam were investigated (Satar et al., 2018). It has been reported that most of the tested populations are highly resistant to these active substances. The highest resistance was 2060 times for imidacloprid in the Antalya (Kumluca) population, and the lowest resistance was 5.36 times for thiamethoxam in the Hatay (Samandağ) population (Satar et al., 2018).

Insecticide resistance in $B$. tabaci populations is a serious problem in Turkey and around the world. The United States, Israel, Greece, Spain, Iran, Pakistan, India, Morocco, Egypt and some other countries have reported resistance in B. tabaci to active substances from many classes (Wool and Greenberg, 1990; Dittrich et al., 1990; Cahill et al., 1996; Elebert and Nauen, 2000; Palumbo et al., 2001; Kranthi et al., 2002; Ahmad et al., 2002; Nauen et al., 2002; El Kady and Devine, 2003; Javed et al., 2003; Horowitz et al., 2004, 2005; Roditakis et al., 2005; Nauen and Denholm, 2005; Basij et al., 2010; Gorman et al., 2010; Ma et al., 2010; Schuster et al., 2010; Wang et al., 2010; Ahmad and Akhtar, 2018; Bielza et al., 2019). In the APRD (Arthropod Pesticide Resistance Database), it has been recorded that $B$. tabaci resists 56 different active substances. The best known of these active ingredients are imidacloprid, acetamiprid, thiamethoxam (neonicotinoids); cypermethrin, deltamethrin, (pyrethroids); chlorpyrifos, malathion (organophosphates); methomyl, carbosulfan (carbamates); pyriproxyfen (juvenile hormone mimics); spiromesifen, spirotetramat (tetronic and tetramic acid derivatives) and 
endosulfan (cyclodiene organochlorine) (APRD, 2020). Greece is one of the geographically closest countries to Turkey and has also carried out a similar survey in the same time period (Roditakis et al., 2005). In this study, high levels of resistance were found in $B$. tabaci greenhouse populations from Greece to neonicotinoid, cyclodiene, pyrethroid and organophosphate insecticides. Resistance levels for bifenthrin, $\alpha$-cypermethrin, pirimiphos-methyl, endosulfan and imidacloprid in greenhouse populations have been reported to reach 23, 80, 18, 58 and 730 times, respectively. However, a $B$. tabaci population taken from open melon fields was found to be more sensitive than the referenced susceptible population (SUD-S) (Roditakis et al., 2005). The results of this research are largely in line with our findings. It was also determined in our study that susceptible populations may be present in areas where insecticides are used little or not at all. On the other hand, insecticide resistance in greenhouse populations where insecticides were used frequently was generally detected at high levels.

\section{Conclusion}

According to the results of this study, most of the B. tabaci populations from the Mediterranean and Aegean regions of Turkey had significant levels of resistance to imidacloprid, lambda-cyhalothrin and endosulfan. In other studies, B. tabaci populations from Turkey were noted to be resistant to other active substances. Worldwide resistance screening of $B$. tabaci shows that resistance is a common problem at the global level and is not limited to Turkish populations. All of these results indicate that chemical management may be inadequate against $B$. tabaci populations due to their insecticide resistance. Unfortunately, this situation is not limited to only $B$. tabaci. The same problem has been observed in other important pests, such as Frankliniella occidentalis and Tetranychus urticae. In summary, it should be taken into consideration that chemical management alone against pests is currently insufficient. More attention should be paid to other options, such as biological control and cultural measures. To reduce the selection pressure on pests, reducing the pesticide application frequency or rotating insecticides with different action mechanisms is necessary. The resistance levels of populations should be routinely monitored, and chemical management should be performed within the scope of resistance management programmes that include preventive tactics.

Acknowledgement. We thank the TUBITAK for their contribution to the TOVAG-104O312 project.

Conflict of interests. The authors declare that they have no conflict of interests.

\section{REFERENCES}

[1] Ahmad, M., Arif, M. I., Ahmad, Z., Denholm, I. (2002): Cotton whitefly (Bemisia tabaci) resistance to organophosphate and pyrethroid insecticides in Pakistan. - Pest Management Science 58(2): 203-208.

[2] Ahmad, M., Akhtar, K. P. (2018): Susceptibility of cotton whitefly Bemisia tabaci (Hemiptera: Aleyrodidae) to diverse pesticides in Pakistan. - Journal of Economic Entomology 111(4): 1834-1841.

[3] Anonymous (2020): Pesticide Use. - Ministry of Environment and Urbanisation, https://cevreselgostergeler.csb.gov.tr/tarim-ilaci-pestisit-kullanimi-i-85834, Access date: 02.07.2020. 
[4] APRD (Arthropod Pesticide Resistance Database) (2020): Bemisia tabaci. https://www.pesticideresistance.org/display.php?page=species\&arId=505, Access date: 26.03.2020.

[5] Basij, M., Talebi, K., Ghadamyari, M., Hosseininaveh, V., Salami, S. A. (2017): Status of resistance of Bemisia tabaci (Hemiptera: Aleyrodidae) to neonicotinoids in Iran and detoxification by cytochrome P450-dependent Monooxygenases. - Neotropical Entomology 46: 115-124.

[6] Bielza, P., Moreno, I., Belando, A., Gràvalos, C., Izquierdo, J., Nauen, R. (2019): Spiromesifen and spirotetramat resistance in field populations of Bemisia tabaci Gennadius in Spain. - Pest Managment Science 75: 45-52.

[7] Cahill, M., Gorman, K., Day, S., Denholm, I. (1996): Baseline determination and detection of resistance to imidacloprid in Bemisia tabaci (Homoptera: Aleyrodidae). - Bulletin of Entomological Research 86: 343-349.

[8] Croft, A. B. (1990): Developing a Philosophy and Program of Pesticide Resistance Management. - In: Roush, R. T., Tabashnik, B. E. (eds.) Pesticide Resistance in Arthropods. Chapman and Hall, Newyork and London, pp. 277-296.

[9] Dağl1, F., Yükselbaba, U., İkten, C., Topakçı, N., Göçmen, H. (2020): Molecular identification of cotton whitefly Bemisia tabaci Genn. (Hemiptera: Aleyrodidae) populations of Turkey based on mitochondrial cytochrome oxidase subunit I. - Applied Ecology and Environmental Research 18(2): 2351-2361.

[10] Dittrich, V., Ernst, G. H., Ruesch, O., Uk, S. (1990): Resistance mechanisms in sweetpotato whitefly (Homoptera: Aleyrodidae) populations from Sudan, Turkey, Guatemala, and Nicaragua. - Journal of Economic Entomology 83(5): 1665-1670.

[11] El Kady, H., Devine, D. J. (2003): Insecticide resistance in Egyptian populations of cotton whitefly, Bemisia tabaci (Genn.) (Hemiptera: Aleyrodidae). - Pest Management Science 59(8): 865-871.

[12] Elbert, A., Nauen, R. (2000): Resistance of Bemisia tabaci (Genn.) (Homoptera: Aleyrodidae) to insecticides in southern Spain with special reference to neonicotinoids. Pest Management Science 56(1): 60-64.

[13] EPPO (2020): Bemisia tabaci. - EPPO Global Database, Distrubition, https://gd.eppo.int/taxon/BEMITA/distribution, Access date: 26.03.2020.

[14] Erdogan, C., Moores, G. D., Gurkan, M. O., Gorman, K. J., Denholm, I. (2008): Insecticide resistance and biotype status of populations of the tobacco whitefly Bemisia tabaci (Hemiptera: Aleyrodidae) from Turkey. - Crop Protection 27: 600-605.

[15] FAO (2020): Pesticides Use. - http://www.fao.org/faostat/en/\#data/RP/visualize, Access date: 23.03.2020.

[16] Göçmen, H., Özgür, A. F. (1990): Migration of cotton whitefly Bemisia tabaci (Genn.) (Homoptera:Aleyrodidae) between various host plants and its population changes. Çukurova University, Institue of Natural and Applied Science, Journal of Science and Engineering 4(3): 115-129. (in Turkish).

[17] Gorman, K., Slater, R., Blande, J. D., Clarke, A., Wren, J., McCaffery, A., Denholm, I. (2010): Cross-resistance relationships between neonicotinoids and pymetrozine in Bemisia tabaci (Hemiptera: Aleyrodidae). - Pest Management Science 66: 1186-1190.

[18] Horowitz, A. R., Kontsedalov, S., Ishaaya, I. (2004): Dynamics of resistance to the neonicotinoids acetamiprid and thiamethoxam in Bemisia tabaci (Homoptera: Aleyrodidae). - Journal of Economic Entomology 97(6): 2051-2056.

[19] Horowitz, A. R., Kontsedalov, S., Khasdan, V., Ishaaya, I. (2005): Biotypes B and Q of Bemisia tabaci and Their Relevance to Neonicotinoid and Pyriproxyfen Resistance. Archives of Insect Biochemistry and Physiology 58: 216-225.

[20] IRAC (Insecticide Resistance Action Committe) Team (2016): New resistance database figures. - http://www.irac-online.org/documents/resistance-database-team-update-2016/, $50^{\text {th }}$ IRAC International Meeting, 5- $8^{\text {th }}$ April, Dublin, p. 3. Access date: 10.04.2019. 
[21] Javed, N., Viner, R., Williamson, S. M., Field, M. L., Devonshire, L. A., Moores, G. D. (2003): Characterization of acetylcholinesterases, and their genes, from the hemipteran species Myzus persicae (Sulzer), Aphis gossypii (Glover), Bemisia tabaci (Gennadius) and Trialeurodes vaporariorum (Westwood). - Insect Molecular Biology 12(6): 613-620.

[22] Kranthi, K. R., Jadhav, D. R., Kranthi, S., Wanjari, R. R., Ali, S. S., Russel, D. A. (2002): Insecticide resistance in five major insect pests of cotton in India. - Crop Protection 21(6): 449-460.

[23] Ma, W., Li, X., Dennehy, T., Lei, C., Wang, M., Degain, B., Nichols, R. (2010): Pyriproxyfen Resistance of Bemisia tabaci (Homoptera: Aleyrodidae) Biotype B: Metabolic Mechanism. - Journal of Economic Entomology 103: 158-165.

[24] Nauen, R., Stumpf, N., Elbert, A. (2002): Toxicological and mechanistic studies on neonicotinoid cross resistance in Q-type Bemisia tabaci (Hemiptera: Aleyrodidae). - Pest Management Science 58: 868-875.

[25] Nauen, R., Denholm, I. (2005): Resistance of insect pests to neonicotinoid insecticides: Current status and future prospects. - Archives of Insect Biochemistry and Physiology 58: 200-215.

[26] Oliviera, M. R. V., Henneberry, T. J., Anderson, P. (2001): History, current status, and collaborative research projects for Bemisia tabaci. - Crop protection 20(9): 709-723.

[27] Palumbo, J. C., Horowitz, A. R., Prabhaker, N. (2001): Insecticidal control and resistance management for Bemisia tabaci. - Crop protection 20(9): 739-765.

[28] Roditakis, E., Roditakis, N. E., Tsagkarakou, A. (2005): Insecticide resistance in Bemisia tabaci (Homoptera: Aleyrodidae) populations from Crete. - Pest Management Science 61: 577-582.

[29] Satar, G., Ulusoy, M. R., Nauen, R., Ke, D. (2018): Neonicotinoid insecticide resistance among populations of Bemisia tabaci in the Mediterranean region of Turkey. - Bulletin of Insectology 71(2): 171-177.

[30] Schuster, D. J., Mann, R. S., Toapanta, M., Cordero, R., Thompson, S., Cyman, S., Shurtleff, A., Morris, R. F., II. (2010): Monitoring neonicotinoid resistance in biotype B of Bemisia tabaci in Florida. - Pest Management Science 66: 186-195.

[31] Soderlund, D. M., Bloomquist, J. R. (1990): Moleculer Mechanisms of Insecticide Resistance. - In: Roush, R. T., Tabashnik, B. E. (eds.) Pesticide Resistance in Arthropods. Chapman and Hall, Newyork and London, pp. 58-96.

[32] Şahin, İ., İkten, C. (2017): Neonicotinoid resistance in Bemisia tabaci (Genn., 1889) (Hemiptera: Aleyrodidae) populations from Antalya, Turkey. - Turkish Journal of Entomology 41(2): 169-175.

[33] Ünal Bahşi, Ş., Dağl1, F., İkten, C., Göçmen, H. (2012): Susceptibility level of Bemisia tabaci (Gennadius) (Hemiptera: Aleyrodidae) populations collected from Antalya to Acetamiprid, Chlorpyrifos-ethyl and Cypermethrin. - Mediterranean Agricultural Sciences 25(1): 17-22.

[34] Wang, Z., Yan, H., Yang, Y., Wu, Y. (2010): Biotype and insecticide resistance status of the whitefly Bemisia tabaci from China. - Pest Management Science 66(12): 1360-1366.

[35] Wool, D., Greenberg, S. (1990): Esterase activity in whiteflies (Bemisia tabaci) in Israel in relation to insecticide resistance. - Entomologia Experimentalis et Applicata 57: 251-258. 